\title{
Effects of talc and clay addition on pressureless sintering of porous $\mathrm{Si}_{3} \mathbf{N}_{4}$ ceramics
}

\author{
YU FANGLI, YANG JIANFENG*, XUE YAOHUI ${ }^{\dagger}$, DU JUN*, LU YUAN and \\ GAO JIQIANG \\ State Key Laboratory for Mechanical Behaviour of Materials, Xi'an Jiaotong University, Xi'an 710049, P.R. China \\ ${ }^{\dagger}$ The School of Electronic and Information Engineering, Xi' an Jiaotong University, Xi' an 710049, P.R. China \\ ${ }^{\dagger \dagger}$ National Key Laboratory of Remanufacture, No. 21, DuJiaKan, ChangXinDian, Beijing 100072, P.R. China
}

MS received 21 July 2008; revised 15 September 2008

\begin{abstract}
Porous $\mathrm{Si}_{3} \mathrm{~N}_{4}$ ceramics were successfully synthesized using cheaper talc and clay as sintering additives by pressureless sintering technology and the microstructure and mechanical properties of the ceramics were also investigated. The results indicated that the ceramics consisted of elongated $\beta-\mathrm{Si}_{3} \mathrm{~N}_{4}$ and $\operatorname{small~}_{\mathrm{Si}_{2}} \mathrm{~N}_{2} \mathrm{O}$ grains. Fibrous $\beta-\mathrm{Si}_{3} \mathrm{~N}_{4}$ grains developed in the porous microstructure, and the grain morphology and size were affected by different sintering conditions. Adding $20 \%$ talc and clay sintered at $1700^{\circ} \mathrm{C}$ for $2 \mathrm{~h}$, the porous $\mathrm{Si}_{3} \mathrm{~N}_{4}$ ceramics were obtained with excellent properties. The final mechanical properties of the $\mathrm{Si}_{3} \mathrm{~N}_{4}$ ceramics were as follows: porosity, $P_{0}=45.39 \%$; density, $\rho=1.663 \cdot \mathrm{g} \cdot \mathrm{cm}^{-3}$; flexural strength, $\sigma_{\mathrm{b}}($ average $)=$ 131.59 MPa; Weibull modulus, $m=16 \cdot 20$.
\end{abstract}

Keywords. Talc; clay; pressureless sintering; porous $\mathrm{Si}_{3} \mathrm{~N}_{4}$; mechanical properties; Weibull distribution.

\section{Introduction}

Porous ceramic materials have many industrial applications as filtering materials including uses as high temperature gas filters, separation membranes, bioreactors and catalyst supports (Zaman and Chakma 1994; Jonker and Potgieter 2005). In particular, porous $\mathrm{Si}_{3} \mathrm{~N}_{4}$ ceramics with elongated $\beta-\mathrm{Si}_{3} \mathrm{~N}_{4}$ grains show superior mechanical properties, such as high strength, good thermal shock resistance (Arnold et al 1996; Shigegaki et al 1997), high strain and damage tolerance (Kawai and Yamakawa 1997; Inagaki et al 2000). In general, for the densification of porous $\mathrm{Si}_{3} \mathrm{~N}_{4}$ ceramics, the liquid phase sintering is carried out using different sintering additives such as $\mathrm{MgO}, \mathrm{Al}_{2} \mathrm{O}_{3}$, $\mathrm{Y}_{2} \mathrm{O}_{3}, \mathrm{Yb}_{2} \mathrm{O}_{3}$ and other rare oxides or their combination (Kawai and Yamakawa 1998; Yang et al 2000, 2006; Lee and Kim 2004). However, to minimize the cost of $\mathrm{Si}_{3} \mathrm{~N}_{4}$ ceramics, the choice of sintering additive with reasonable costs as well as decreasing the sintering temperature are required, especially, for the application of intermediate temperature. In this point of view, the cheaper talc and clay, which are aluminosilicates containing different amounts of calcium, potassium, or sodium can be considered as low temperature and low cost sintering additives. In the glass ceramics, the talc and clay was widely used as a flux to decrease the vitrifying temperature of ceramics

*Author for correspondence (yang155@mail.xjtu.edu.cn) during firing and forming a glassy phase. Compared to other additives, the talc and clay additives offered an opportunity to reduce the cost of $\mathrm{Si}_{3} \mathrm{~N}_{4}$ ceramics.

In this work, porous $\mathrm{Si}_{3} \mathrm{~N}_{4}$ ceramics were successfully synthesized with $\alpha-\mathrm{Si}_{3} \mathrm{~N}_{4}$ as starting materials and the cheaper talc and clay as sintering additives by pressureless sintering technology. The effects of the talc and clay on the ceramics phase composition, microstructure and mechanical properties were investigated.

\section{Experimental}

\subsection{Preparation of samples}

Commercial $\alpha-\mathrm{Si}_{3} \mathrm{~N}_{4}$ powder (Shanghai Junyu Co. Ltd., Shanghai, China; $\alpha-\mathrm{Si}_{3} \mathrm{~N}_{4}$ ratio: $>95 \%$, mean particle size: $1.2 \mu \mathrm{m}$, main impurities by weight: $\mathrm{O}=1.6 \% ; \mathrm{C}<0.2 \%$; $\mathrm{Cl}, \mathrm{Fe}, \mathrm{Ca}$, and $\mathrm{Al}_{2} \mathrm{O}_{3}<80 \mathrm{ppm}$ ) was used as the starting powder, and various contents (10-40 wt\%) of talc and clay with a weight ratio of $8: 2$ were used as sintering additives. The chemical compositions of talc and clay given in weight percentages of oxides are given in table 1 . The compositions of test samples are listed in table 2 .

The mixtures were wet-milled in methanol for $24 \mathrm{~h}$, using high-purity $\mathrm{Si}_{3} \mathrm{~N}_{4}$ media. The obtained slurry was dried and sieved through a $150 \mu \mathrm{m}$ screen. The mixed powders were then pressed under $20 \mathrm{MPa}$, to form rectangular bars measuring $55 \times 6 \times 5 \mathrm{~mm}$. The green bodies were placed in a BN-coated graphite crucible and sintered 
Table 1. Chemical compositions of talc and clay.

\begin{tabular}{lrrrrrrrrc}
\hline & \multicolumn{1}{c}{ Compositions (wt\%) } \\
\cline { 2 - 9 } Raw materials & $\mathrm{SiO}_{2}$ & $\mathrm{Al}_{2} \mathrm{O}_{3}$ & $\mathrm{Fe}_{2} \mathrm{O}_{3}$ & $\mathrm{TiO}_{2}$ & $\mathrm{CaO}$ & $\mathrm{MgO}$ & $\mathrm{K}_{2} \mathrm{O}$ & $\mathrm{Na}_{2} \mathrm{O}$ & Ignition loss \\
\hline Talc & 60.44 & 0.27 & 0.34 & - & 1.07 & 30.37 & - & - & 3.32 \\
Clay & 46.00 & 35.90 & 0.95 & 0.03 & 0.40 & 0.01 & 0.21 & 0.02 & 4.96 \\
\hline
\end{tabular}

Table 2. Compositions of the starting raw materials of samples.

\begin{tabular}{ll}
\hline Samples & \multicolumn{1}{c}{ Composition (wt\%) } \\
\hline$S 1$ & $90 \% \alpha-\mathrm{Si}_{3} \mathrm{~N}_{4}+10 \%$ talc and clay \\
$S 2$ & $80 \% \alpha-\mathrm{Si}_{3} \mathrm{~N}_{4}+20 \%$ talc and clay \\
$S 3$ & $70 \% \alpha-\mathrm{Si}_{3} \mathrm{~N}_{4}+30 \%$ talc and clay \\
$S 4$ & $60 \% \alpha-\mathrm{Si}_{3} \mathrm{~N}_{4}+40 \%$ talc and clay \\
\hline
\end{tabular}

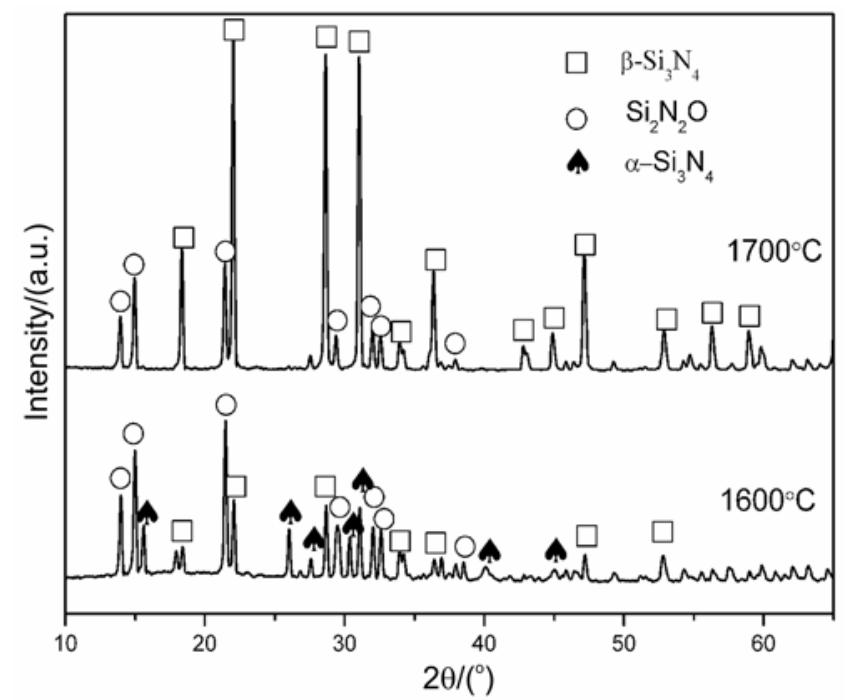

Figure 1. XRD patterns of sample, $S 2$, sintered at $1600^{\circ} \mathrm{C}$ and $1700^{\circ} \mathrm{C}$

in graphite resistance furnace (High multi-5000 Fijidempa Co. Ltd., Osaka, Japan) at various temperatures under a nitrogen-gas pressure of $0.3 \mathrm{MPa}$. The heating rate was $10-20^{\circ} \mathrm{C} / \mathrm{min}$ and holding time was $2 \mathrm{~h}$.

\subsection{Examination of properties}

The three-point bending strength was measured on sample bars with a span of $16 \mathrm{~mm}$ at a crosshead speed of $0.5 \mathrm{~mm} / \mathrm{min}$ by an instrument (model Instron 1195 , Instron Co., Buckinghamshire, England). Each final value was averaged over five measurements.

The bulk density of the sintered products was measured by the Archimedes displacement method. Crystalline phases were identified by an X-ray diffractometry (XRD, D/MAX-2400X, Rigaku Co., Tokyo, Japan) analysis. Microstructure was characterized by a scanning electron microscope (SEM, JSM-35C, JEOL, Tokyo, Japan).

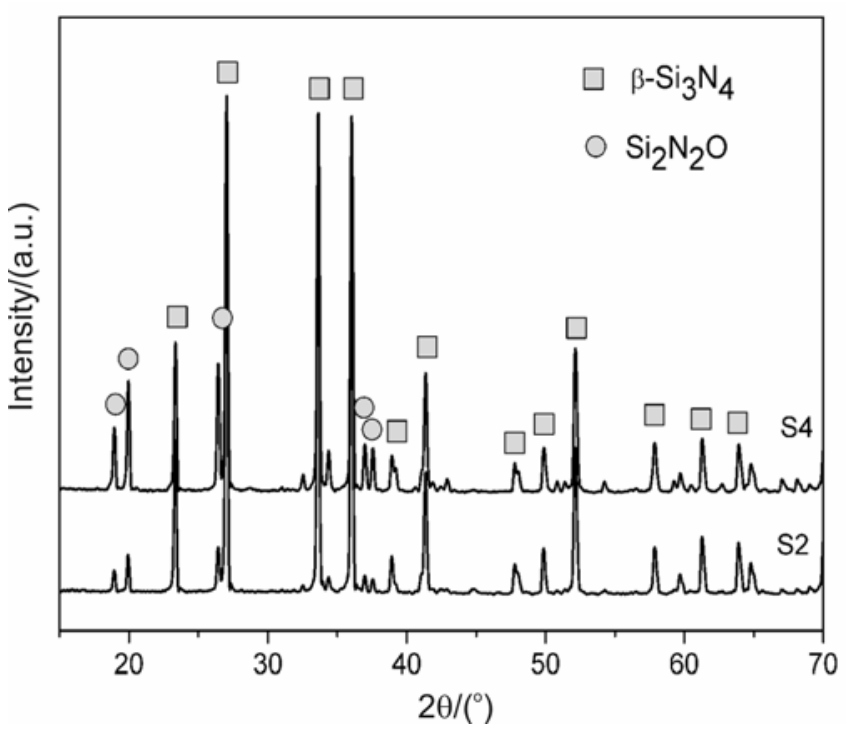

Figure 2. XRD patterns of samples, $S 2$ and $S 4$.

\section{Results and discussion}

\subsection{Phase composition and microstructure}

The XRD results of the sample, $S 2$, are shown in figure 1 . It could be seen that peaks of $\beta-\mathrm{Si}_{3} \mathrm{~N}_{4}, \mathrm{Si}_{2} \mathrm{~N}_{2} \mathrm{O}$ and $\alpha$ $\mathrm{Si}_{3} \mathrm{~N}_{4}$ could be observed, the $\alpha-\beta \mathrm{Si}_{3} \mathrm{~N}_{4}$ phase transformation could not take place completely when sintered at $1600^{\circ} \mathrm{C}$, so that a mass of $\alpha-\mathrm{Si}_{3} \mathrm{~N}_{4}$ remained in the sample, and it was noticed that comparatively strength of $\mathrm{Si}_{2} \mathrm{~N}_{2} \mathrm{O}$ were detected together with $\beta-\mathrm{Si}_{3} \mathrm{~N}_{4}$ and $\alpha-\mathrm{Si}_{3} \mathrm{~N}_{4}$ phases. $\mathrm{Si}_{2} \mathrm{~N}_{2} \mathrm{O}$ and $\beta-\mathrm{Si}_{3} \mathrm{~N}_{4}$ existed by the $\alpha / \beta$ phase transformation of $\mathrm{Si}_{3} \mathrm{~N}_{4}$. Heated at $1700^{\circ} \mathrm{C}$, the reaction took place completely, so that $\beta-\mathrm{Si}_{3} \mathrm{~N}_{4}$ and $\mathrm{Si}_{2} \mathrm{~N}_{2} \mathrm{O}$ were detected.

The XRD patterns of samples $S 2$ and $S 4$ sintered at $1700^{\circ} \mathrm{C}$ for $2 \mathrm{~h}$ are shown in figure 2 . The main phase was $\beta-\mathrm{Si}_{3} \mathrm{~N}_{4}$, implying an almost complete $\alpha-\beta$ phase transformation, and the secondary phase was $\mathrm{Si}_{2} \mathrm{~N}_{2} \mathrm{O}$ alone, the formation of $\mathrm{Si}_{2} \mathrm{~N}_{2} \mathrm{O}$ phase was reported in the phase relation of $\mathrm{Si}_{3} \mathrm{~N}_{4}-\mathrm{SiO}_{2}-\mathrm{Al}_{2} \mathrm{O}_{3}$ systems at high temperature (Mitomo et al 1989). With an increase in talc and clay, the amount of $\mathrm{Si}_{2} \mathrm{~N}_{2} \mathrm{O}$ increased.

The microstructures of sample, $S 2$, sintered at 1600 and $1700^{\circ} \mathrm{C}$ are shown in figure 3 . The microstructure of the sample, $S 2$, sintered at $1600^{\circ} \mathrm{C}$ consisted of fine and equiaxed grains (figure 3 (a)). The average grain size was 

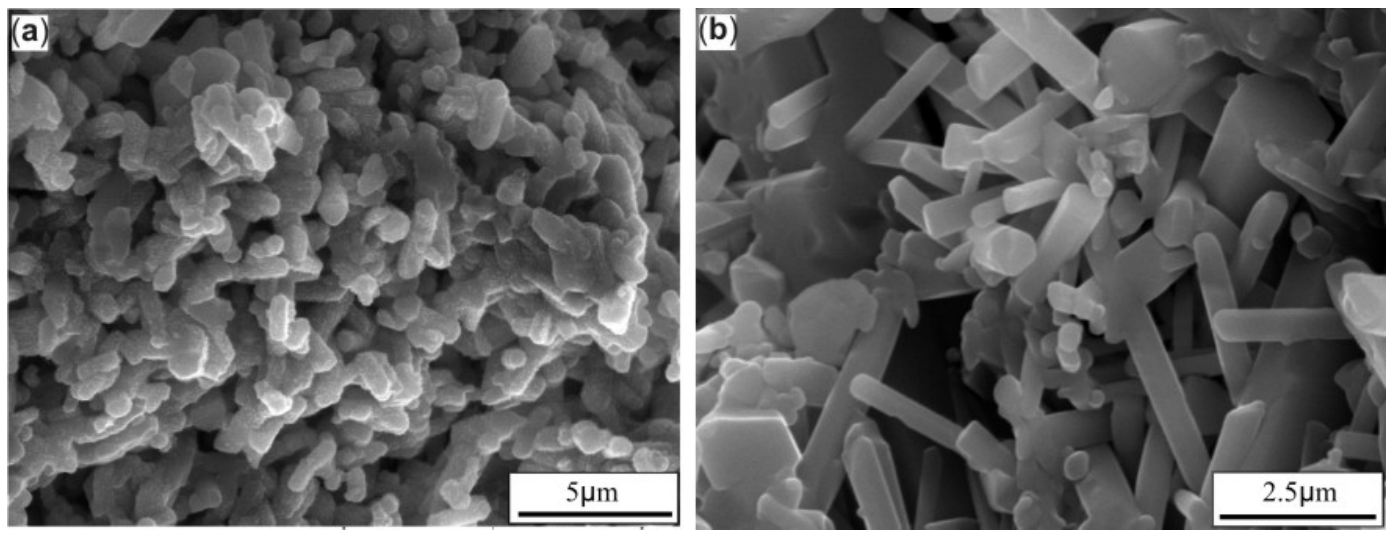

Figure 3. SEM images of sample, $S 2$, sintered at $1600^{\circ} \mathrm{C}(\mathbf{a})$ and $1700^{\circ} \mathrm{C}(\mathbf{b})$.
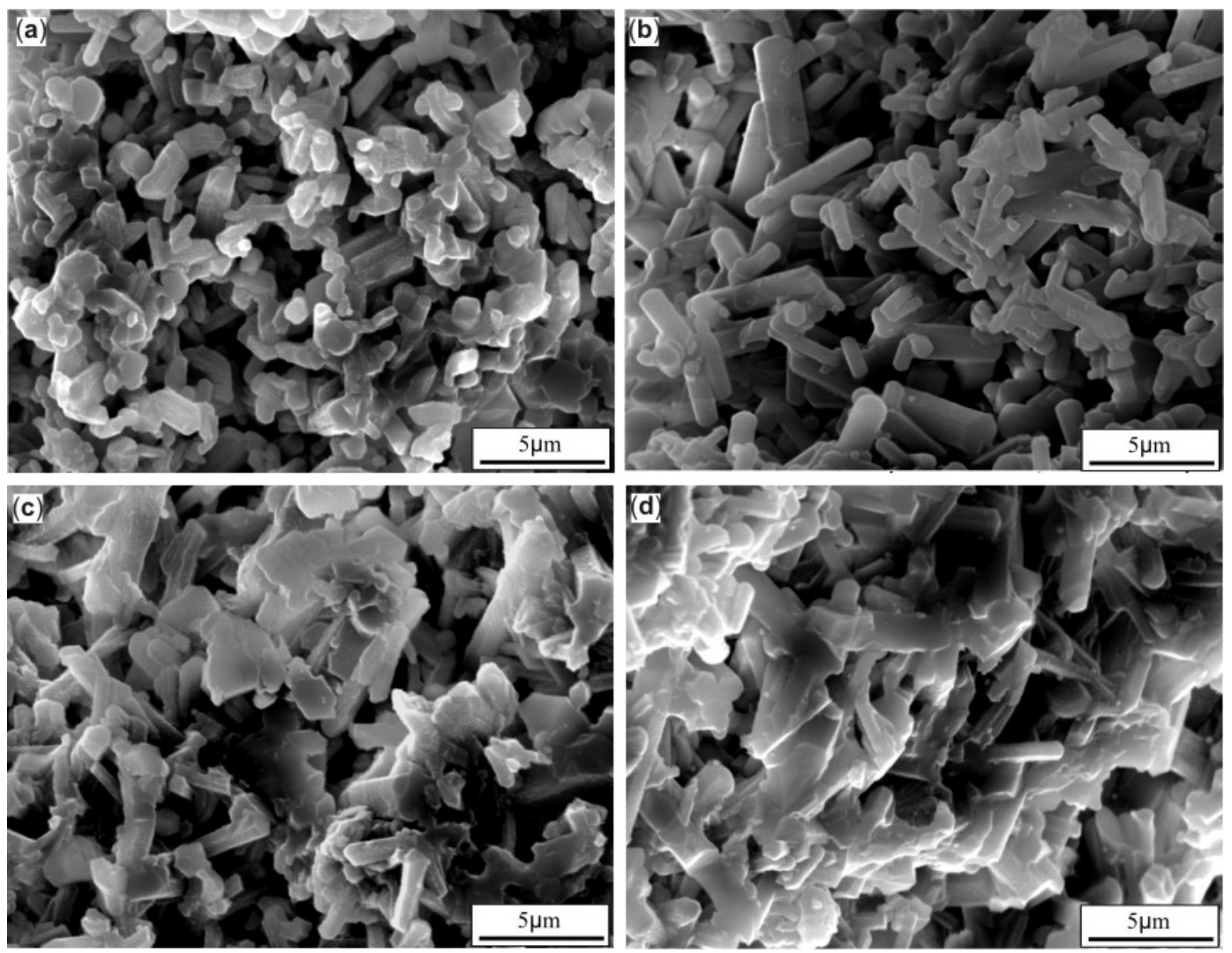

Figure 4. SEM images of porous $\mathrm{Si}_{3} \mathrm{~N}_{4}$ ceramics: (a) $S 1$, (b) $S 2$, (c) $S 3$ and (d) $S 4$. The samples were sintered at $1700^{\circ} \mathrm{C}$ for $2 \mathrm{~h}$.

almost the same as that of the starting powder, indicating part phase transformation, which could also be confirmed by XRD analysis as $\alpha-\mathrm{Si}_{3} \mathrm{~N}_{4}$ peaks were identified. Because the density after sintering exhibited part change, complete sintering was not achieved at this temperature. Increasing the sintering temperature caused the formation and development of $\beta-\mathrm{Si}_{3} \mathrm{~N}_{4}$ grains, indicating enhanced phase transformation and grain growth. When the sample, $S 2$, was sintered at $1700^{\circ} \mathrm{C}$, very fine, fibrous $\beta-\mathrm{Si}_{3} \mathrm{~N}_{4}$ grains were obtained (figure 3 (b)).
Figure 4 shows microstructures of $\mathrm{Si}_{3} \mathrm{~N}_{4}$ ceramics with varying additive contents. From figure 4(a), fine equiaxial $\beta-\mathrm{Si}_{3} \mathrm{~N}_{4}$ grains could be seen. Increasing the talc and clay content resulted in the formation of large, elongated $\mathrm{Si}_{3} \mathrm{~N}_{4}$ grains in the fine matrix, as shown in figure $4(\mathrm{~b})$. However, that with a large additive content exhibited a coarse and conglomerated $\mathrm{Si}_{3} \mathrm{~N}_{4}$ grains (figures $4(\mathrm{c})$, (d)). The explanation could be given by the following reasons. Densification and $\alpha-\beta$ phase transformation were two phenomena which occurred during the sintering of $\mathrm{Si}_{3} \mathrm{~N}_{4}$ 
Table 3. Mechanical properties of $\mathrm{Si}_{3} \mathrm{~N}_{4}$ ceramics sintered sample, $S 2$, at 1600 and $1700^{\circ} \mathrm{C}$.

\begin{tabular}{lcccc}
\hline Temperature $\left({ }^{\circ} \mathrm{C}\right)$ & Porosity $(\%)$ & Density $\left(\mathrm{g} \cdot \mathrm{cm}^{-3}\right)$ & $\begin{array}{c}\text { Relative } \\
\text { density }(\%)\end{array}$ & $\begin{array}{c}\sigma_{\mathrm{b}}(\mathrm{average}) \\
(\mathrm{MPa})\end{array}$ \\
\hline 1600 & $40 \cdot 87$ & 1.534 & $48 \cdot 12$ & $76 \cdot 30$ \\
1700 & 45.39 & 1.663 & $52 \cdot 13$ & 131.59 \\
\hline
\end{tabular}

ceramics. For liquid phase sintering, an effective liquid phase with a sufficient volume fraction, good wettability to solid phase and appreciable solubility of the solid was required. Both the densification and phase transformation were greatly influenced by the type and amount of the liquid phase. According to $\mathrm{MgO}-\mathrm{Al}_{2} \mathrm{O}_{3}-\mathrm{SiO}_{2}$ phase diagram, most of the components of the talc and clay powder could be changed into an amorphous phase at $1355^{\circ} \mathrm{C}$. With the additive content, the densification was achieved due to particle rearrangement and with a small additive content, and it was achieved due to particle rearrangement and coalescence. This speculation was supported by the result that the densification depended strongly on the sintering additive content due to the fact that a large amount of the boundary liquid phase facilitates the particle rearrangement. The phase transformation and grain growth in $\mathrm{Si}_{3} \mathrm{~N}_{4}$ ceramics was controlled by the diffusion mechanism through the liquid grain-boundary film, or the interface reaction (Lifzhitz and Slyozov 1961; Hampshire and Jack 1983). The main factor that determined the ratecontrolling mechanism was the diffusion velocity of $\mathrm{Si}$ and $\mathrm{N}$ atoms in the liquid phase, the interface reaction rate-controlling for high diffusion velocity and diffusion controlling for low diffusion velocity. Sintering additives affected these behaviours through the glass phase (Emoto et al 1999). However, the phase transformation and grain growth were suppressed by the large increase in the talc and clay contents. The large additive content resulted in a high viscosity of the liquid phase in the $\mathrm{MgO}-\mathrm{Al}_{2} \mathrm{O}_{3}-$ $\mathrm{SiO}_{2}$, this led to slower diffusion rate for $\mathrm{Si}$ and $\mathrm{N}$ through the liquid phase, and thus, the phase transformation and grain growth were retarded.

\subsection{Mechanical properties}

The mechanical properties of the sample, $S 2$, sintered at 1600 and $1700^{\circ} \mathrm{C}$ are listed in table 3 . When the sample, $S 2$, was sintered at $1600^{\circ} \mathrm{C}$, at which little phase transformation occurred, the flexural strength was very low. Usually, phase transformation starts in the temperature range $1600 \sim 1650^{\circ} \mathrm{C}$, and grain growth starts at the same time. Of course, increasing the sintering temperature will accelerate the development of large, elongated grains. In the present study, high strength was obtained for the sample, $S 2$, sintered at $1700^{\circ} \mathrm{C}$, which indicated that finesized, fibrous $\mathrm{Si}_{3} \mathrm{~N}_{4}$ grains, rather than coarse grains, favour high strength in porous $\mathrm{Si}_{3} \mathrm{~N}_{4}$ ceramics, which was in accordance with the SEM above.
Table 4 exhibits the porosity, density and flexural strength of $\mathrm{Si}_{3} \mathrm{~N}_{4}$ ceramics. Clearly, the flexural strength decreased as porosity increased. The sample, $S 2$, with $20 \%$ talc and clay contents exhibited excellent properties. This could be explained as being due to the coexisting effects between the microstructure and the remaining glass phase. Fibrous $\beta-\mathrm{Si}_{3} \mathrm{~N}_{4}$ grains were known to enhance the flexural strength of $\mathrm{Si}_{3} \mathrm{~N}_{4}$ ceramics (Yang et al 2001), most likely because the fibrous $\beta-\mathrm{Si}_{3} \mathrm{~N}_{4}$ grains were beneficial for strengthening by grain bridging and pullout. With increasing additive content, the matrix grains were refined, but the amount of the grain-boundary glassy phase increased, it was very likely that the former increased the flexural strength while the latter decreased it.

\subsection{Weibull distribution}

For a given ceramic material the distribution of crack size, shape, and orientation differs from sample to sample. It is experimentally reported that the strength of ceramics varies unpredictably even if identical specimens are tested under identical loading conditions. For analysing flexural strength distribution of the ceramics material, Weibull (1951) proposed a two-parameter distribution function to characterize the strength of brittle materials. The Weibull distribution function has the following expression:

$$
P(\sigma)=1-\exp \left[-\left(\frac{\sigma}{\sigma_{0}}\right)^{m}\right],
$$

where $P(\sigma)$ is the probability of failure at a given stress level ' $\sigma$ ', $m$ the Weibull modulus and $\sigma_{0}$ the scale parameter. The characteristic strength distribution parameter, $m$, indicates the nature, severity and dispersion of flaws. More clearly, a low $m$ value indicates non-uniform distribution of highly variable crack length (broad strength distribution), while a high $m$ value implicates uniform distribution of highly homogeneous flaws with narrower strength distribution. Typically, for structural ceramics, $m$ varies between 5 and 30 , depending on the processing conditions (Bazant 2004), so the Weibull distribution function is widely used to characterize the fracture strength of the porous $\mathrm{Si}_{3} \mathrm{~N}_{4}$ ceramics. Figure 5 shows Weibull statistics analysis where failure probability was plotted vs applied load. This value clearly indicated that these ceramics had comparatively higher flexural strength. 
Table 4. Mechanical properties of $\mathrm{Si}_{3} \mathrm{~N}_{4}$ ceramics.

\begin{tabular}{lcccc}
\hline Sample & Porosity $(\%)$ & Density $\left(\mathrm{g} \cdot \mathrm{cm}^{-3}\right)$ & Relative density $(\%)$ & $\sigma_{\mathrm{b}}$ (average) (MPa) \\
\hline$S 1$ & $46 \cdot 78$ & 1.582 & $49 \cdot 61$ & $103 \cdot 30$ \\
$S 2$ & 45.39 & 1.663 & $52 \cdot 13$ & 131.59 \\
$S 3$ & 41.88 & 1.683 & 52.77 & 114.22 \\
$S 4$ & 12.54 & 2.659 & 68.45 & 184.09 \\
\hline
\end{tabular}

Table 5. Weibull modulus $(m)$ of the samples.

\begin{tabular}{lccccc}
\hline Samples & $S 1$ & \multicolumn{2}{c}{$S 2$} & $S 3$ & $S 4$ \\
\hline Weibull modulus, & 13.71 & $\begin{array}{c}1600\left({ }^{\circ} \mathrm{C}\right) \\
7.419\end{array}$ & $\begin{array}{c}1700\left({ }^{\circ} \mathrm{C}\right) \\
16.20\end{array}$ & 14.03 & 12.25 \\
$m$ & & 7 & & \\
\hline
\end{tabular}

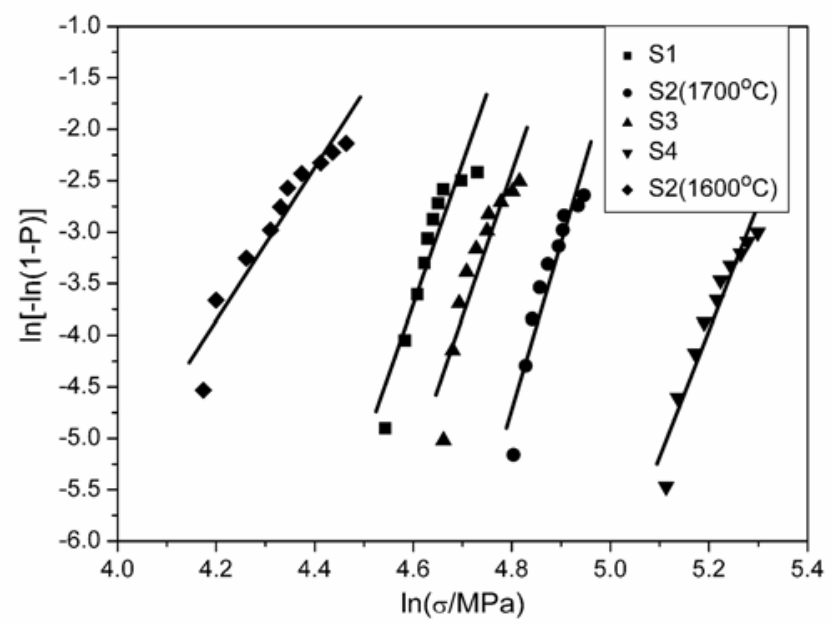

Figure 5. Weibull statistics analysis results of the samples.

All the strength data i.e. datasets $S 1, S 2, S 3$ and $S 4$, are tabulated in table 5 . For $S 2$ sintered at $1700^{\circ} \mathrm{C}$, it could be noted that the Weibull modulus $(m)$ was very high, which indicated uniform distribution of highly homogeneous flaws with narrower strength distribution in sample, $S 2$, sintered at $1700^{\circ} \mathrm{C}$. Adding $20 \%$ talc and clay in the starting powders sintered at $1700^{\circ} \mathrm{C}$ for $2 \mathrm{~h}$, porous $\mathrm{Si}_{3} \mathrm{~N}_{4}$ ceramics were successfully synthesized with excellent properties.

\section{Conclusions}

(I) Using $\alpha-\mathrm{Si}_{3} \mathrm{~N}_{4}$ as starting material, and the cheaper talc and clay as sintering additives, porous $\mathrm{Si}_{3} \mathrm{~N}_{4}$ ceramics were fabricated by pressureless sintering technology, and the composite ceramics consisted of fine, fibrous $\beta-\mathrm{Si}_{3} \mathrm{~N}_{4}$ and small $\mathrm{Si}_{2} \mathrm{~N}_{2} \mathrm{O}$ grains.

(II) The mechanical properties were obtained by adjusting the sintering conditions and additive content. Adding
$20 \%$ talc and clay in the starting powders sintered at $1700^{\circ} \mathrm{C}$ for $2 \mathrm{~h}$, porous $\mathrm{Si}_{3} \mathrm{~N}_{4}$ ceramics were successfully synthesized with excellent properties. The final mechanical properties of the $\mathrm{Si}_{3} \mathrm{~N}_{4}$ ceramics were as follows: porosity, $P_{0}=45.39 \%$; density, $\rho=1.663 \mathrm{~g} \cdot \mathrm{cm}^{-3}$; flexural strength, $\sigma_{\mathrm{b}}$ (average) $=131.59 \mathrm{MPa}$; Weibull modulus, $m=16 \cdot 20$.

\section{Acknowledgements}

This work was supported by the Ministry of Education of the People's Republic of China within the Program for New Century Excellent Talents in University (NCET-040941), and by the Research Fund for the Doctoral Program of National Ministry, Higher Education, under contract no. 20060698008.

\section{References}

Arnold M, Boccaccini A R and Ondracek G 1996 J. Mater. Sci. 31463

Bazant Z P 2004 Prob. Eng. Mech. 19307

Emoto H, Hirotsuru H and Mitomo M 1999 Key Eng. Mater. 159-160 215

Hampshire S and Jack K H 1983 Progress in nitrogen ceramics (ed.) F L Riley (The Hague: Martinus Nijhoff Publisher) pp 225-230

Inagaki Y, Ohji T, Kanzaki S and Shigegaki Y $2000 \mathrm{~J}$. Am. Ceram. Soc. 831807

Jonker A and Potgieter J H 2005 J. Eur. Ceram. Soc. 25 3145

Kawai C and Yamakawa A 1997 J. Am. Ceram. Soc. 80 2705

Kawai C and Yamakawa A 1998 Ceram. Int. 24135

Lee B T and Kim H D 2004 Mater. Sci. Eng. A364 126

Lifzhitz I M and Slyozov V V 1961 J. Phys. Chem. Solids 1935

Mitomo M, Ono S and Asami T 1989 Ceram. Int. 1014

Shigegaki Y, Brito M E, Hirao K, Toriyama M and Kanzaki S 1997 J. Am. Ceram. Soc. 82495

Weibull W 1951 J. Appl. Mech. 18293

Yang J F, Ohji T and Niihar A K 2000 J. Am. Ceram. Soc. 83 2094

Yang J F, Zhang G J and Ohji T $2001 \mathrm{~J}$. Am. Ceram. Soc. 84 1639

Yang J, Yang J F, Shan S Y, Gao J Q and Ohji T 2006 J. Am. Ceram. Soc. 893843

Zaman J and Chakma A 1994 J. Membr. Sci. 921 